\title{
Effect of Weed Control Methods on Growth and Development of Weeds in Sugarcane Saccharum officinarum L. Fields
}

\author{
Nadir F. Almubarak ${ }^{1}$, T. K. Srivastava ${ }^{2}$ \\ ${ }^{1}$ Department of Field Crop Sciences, College of Agriculture, University of Diyala, Baquba City, Iraq \\ ${ }^{2}$ Crop Production Division, Indian Institute of Sugarcane Research, Uttar Pradish, India
}

\section{Email address:}

nadiralmubarak@gmail.com (N. F. Almubarak), nadiralmubarak@agricultur.uodiyala.edu.iq (N. F. Almubarak), tapendrakapil@yahoo.com (T. K. Srivastava)

\section{To cite this article:}

Nadir F. Almubarak, T. K. Srivastava. Effect of Weed Control Methods on Growth and Development of Weeds in Sugarcane Saccharum officinarum L. Fields. International Journal of Applied Agricultural Sciences. Vol. 1, No. 3, 2015, pp. 49-54.

doi: $10.11648 /$ j.jiaas.20150103.11

\begin{abstract}
A field experiment on sugarcane was carried out during 2012-2013 season at the Indian Institute of Sugarcane Research Farm, Lucknow (UP), India to assess the effect of weed control methods on growth and development of weeds in sugarcane. The experiment was applied according to the Randomized Complete Block Design RCBD with three replications. Application of weed control methods was made at tiller stage of sugarcane crop (Variety CoSe 92423). All 14 treatments comprising various doses and time of application of sufentrazone alone or in combination with other weed control methods including other herbicides. The results have shown that the weed density and dry matter accumulation were significantly reduced due to different treatments at all the growth stages of the crop in comparison to that of control. Weed growth in terms of weed density was recorded to be the lowest with sulfentrazone (pre-em; $900 \mathrm{~g}$ ai/ha) at 60, 90 and 120 Day After Planting. However, the dry matter accumulation by weeds was the lowest with three-hoeing as observed at the same growth stages.
\end{abstract}

Keywords: Sugarcane, Weed Control, Sufentrazone, Atrazine, Trash Mulching, Hoeing

\section{Introduction}

Sugarcane crop suffers heavy infestation with weeds that can be controlled manually, mechanically, biologically and chemically[1].The nature of weed problem in sugarcane cultivation is quite different from other field crops because sugarcane is planted with relatively wider row spacing and crop growth is very slow in the initial stages. It takes about 30 - 45 days to complete germination and another 60-75 days for developing full canopy cover [2]. Thus the initial 90-120 days period of crop growth is considered as most critical period of weed competition. Therefore the weed management practice adopted should ensure a weed-free field condition for the first 3-4 months period [3]. Experiments were conducted to evaluate different weed control methods in sugarcane crop. Results revealed that all the weed control methods significantly reduced weed flora and weed biomass as compared to weedy check [4-6].

The specific mode of action for 2,4-D is not completely understood, but like other auxin-type herbicides ethylene evolution is stimulated and uncontrolled growth ensues [7]. Sulfentrazone applied pre-emergence to weeds controls several broadleaf weeds and sedges that are not easily controlled by clomazone[8-10].The trash on decomposition release nutrients which improves the fertility of soil. Mulching with sugarcane trash is, therefore, advantageous over burning which is usually practiced to reduce the incidence of diseases and insect-pests, as in the case of scale insect [3].

In view of information recorded in foregoing paragraphs the present study was carried out to assess the effect of weed control methods on growth and development of weeds in sugarcane.

\section{Materials and Methods}

A field experiment was conducted during 2012-2013 season at the Indian Institute of Sugarcane Research farm, Lucknow (UP), India to assess the effect of weed control methods on growth and development of weeds in sugarcane. Application of weed control methods was made at tiller stage 
of sugarcane crop (Variety CoSe 92423). In all 14 treatments comprising various doses and time of application of sufentrazone alone or in combination with other weed control methods including other herbicides were evaluated in Randomized Complete Block Design (RCBD) with three replications. The treatment details are presented in table 1 .

The soil of the experimental site was Sandy loam with $\mathrm{pH}$ 7.83 and organic carbon $0.40 \%$, however available $\mathrm{N}, \mathrm{P}_{2} \mathrm{O}_{5}$ and $\mathrm{K}_{2} \mathrm{O}$ were determined to be $222.6,16.8$ and $186.1 \mathrm{~kg} / \mathrm{ha}$, respectively. The gross plot size was kept $36 \mathrm{~m}^{2}$ comprising six rows of sugarcane placed at $75 \mathrm{~cm}$ distance from each other. Each experimental unit was separated from other by
$0.5 \mathrm{~m}$ while distance between two replications was $1.5 \mathrm{~m}$. Each experimental unit contained six rows of sugarcane having length of $8 \mathrm{~m}$. Recommended doses of fertilizers including $150 \mathrm{~kg} \mathrm{~N}, 60 \mathrm{~kg} \mathrm{P}_{2} \mathrm{O}_{5}$ and $60 \mathrm{~kg} \mathrm{~K} \mathrm{~K}_{2} \mathrm{O} /$ ha was added to experimental land. Nitrogen was added by application of urea $(46 \% \mathrm{~N})$, in three parts. First part before planting, second part 60 days after planting (DAP) and the third part 90 DAP. Full dose of $\mathrm{P}$ and $\mathrm{K}$ were applied at the time of planting. Bavistin (systemic fungicide) was used for seed treatment@0.2\%,whereas chlorpyriphos (insecticide) was applied at the rate of $5 \mathrm{~L} /$ ha for drenching of sugarcane setts to ward of termites and other insects.

Table 1. Treatment details.

\begin{tabular}{lllll}
\hline No. & Treatment & Time of application & Dose (g ai/ha) & Dose ( mI/ha) \\
\hline $\mathrm{T}_{1}$ & Sulfentrazone $48 \% \mathrm{~F}$ & PPI & 480 & 1000 \\
$\mathrm{~T}_{2}$ & Sulfentrazone $48 \% \mathrm{~F}$ & PPI & 600 & 1250 \\
$\mathrm{~T}_{3}$ & Sulfentrazone $48 \% \mathrm{~F}$ & PPI & 720 & 1500 \\
$\mathrm{~T}_{4}$ & Sulfentrazone $48 \% \mathrm{~F}$ & PPI & 900 & 1875 \\
$\mathrm{~T}_{5}$ & Sulfentrazone $48 \% \mathrm{~F}$ & Pre-em:3DAP & 480 & 1000 \\
$\mathrm{~T}_{6}$ & Sulfentrazone $48 \% \mathrm{~F}$ & Pre-em:3DAP & 600 & 1250 \\
$\mathrm{~T}_{7}$ & Sulfentrazone $48 \% \mathrm{~F}$ & Pre-em:3DAP & 720 & 1500 \\
$\mathrm{~T}_{8}$ & Sulfentrazone $48 \% \mathrm{~F}$ & Pre-em:3DAP & 900 & 1875 \\
$\mathrm{~T}_{9}$ & Atrazine $50 \mathrm{WP}+2,4 \mathrm{D} 80 \% \mathrm{WP}$ & Pre-em:3DAP + 60 DAP & $2000+1000$ & \\
$\mathrm{~T}_{10}$ & Three-hoeing & $60,90,120 \mathrm{DAP}$ & & \\
$\mathrm{T}_{11}$ & Trash mulching & 3 DAP & & \\
$\mathrm{T}_{12}$ & $\mathrm{~T}_{2}+$ one hoeing at $60 \mathrm{DAP}$ & & & \\
$\mathrm{T}_{13}$ & $\mathrm{~T}_{6}+$ one hoeing at $60 \mathrm{DAP}$ & & & \\
$\mathrm{T}_{14}$ & Untreated control (weedy) & & \\
\hline
\end{tabular}

Pre-em: Pre-emergence; DAP: Days after planting

The methods were applied in recording of observations on different parameters as follows:

- Germination percentage

Calculated number of plants that appeared above soil surface 45 DAP.

-Weed Species

All the weeds present in the control experimental plot were uprooted and identified.
-Weed density (number $/ \mathrm{m}^{2}$ )

A quadrant sized $1.0 \mathrm{~m} \mathrm{X} 1.0 \mathrm{~m}$ was thrown randomly in each experimental unit three times and green weed plants those were not affected by herbicides were counted and averaged.

-Percentage of weed control (\%)

Was calculated from the following equation:

$$
\text { Percentage of weed control }=\frac{\text { No. of weeds in control }- \text { No. of weeds in treated plot }}{\text { No. of weeds in control }} \times 100
$$

-Dry weight of weeds (g)

Green weed plants were cut at the soil surface from the same site in the experimental unit three times the quadrant $(1.0 \mathrm{~m} 2)$ was used for counting of weeds for calculating weed density. The weeds samples were air dried under laboratory conditions.

-Inhibition proportion of dry matter (\%): Was calculated from the following equation:

$$
\text { Inhibition proportion of dry matter }=\frac{\text { Weed dry weight in control }- \text { Weed dry weight in treated plot }}{\text { Weed dry weight in control }} \times 100
$$

Analysis of data was done using statistical tools of Randomized Complete Block Design. LSD was used to compare treatments at significant level of 0.05 [11].

\section{Results and Discussion}

Germination percentage

The research findings indicate that weed control methods significantly affected germination of sugarcane (Fig. 1). All the treatments were found effective in increasing the germination in sugarcane compared to the control treatment. Application of atrazine $+2,4-\mathrm{D}$ led to increase in germination to the highest level to $48.6 \%$ compared to the control $(27.6 \%)$. Enhanced germination of sugarcane due to different weed control treatments may be attributed to better availability of moisture and other growth conditions under 
such treatments.

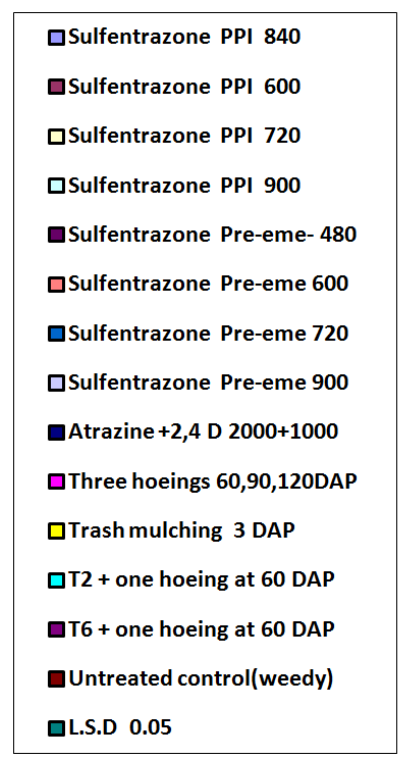

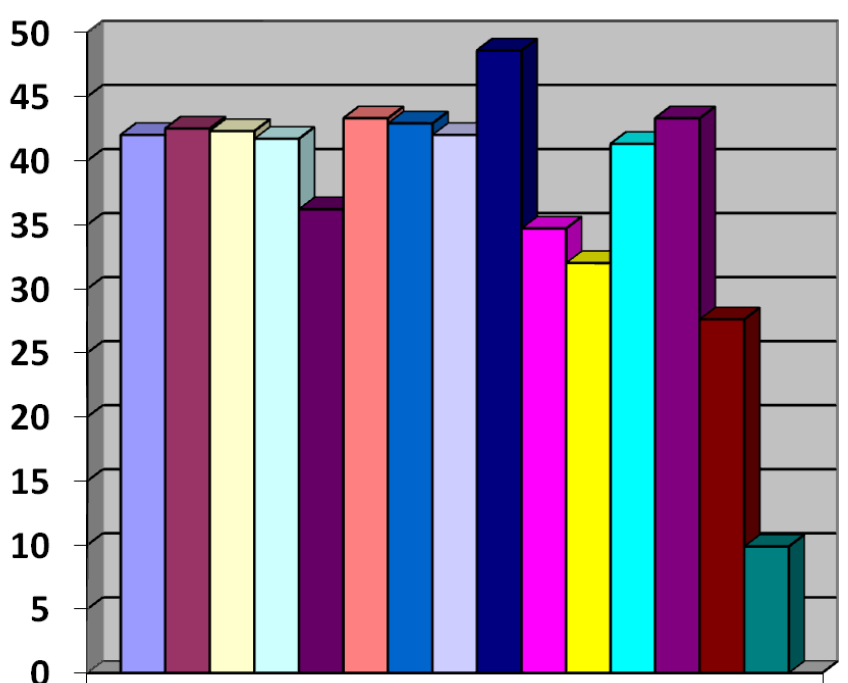

(\%) Germination percentage

Figure 1. Effect of weed control methods on germination (\%) of sugarcane

Weed Density and percentage of weed control

The weed species present in the sugarcane field were: Amaranthus sp., Chenopodium album, Chorcorussp., Portulacaoleracea, Partheniumsp., Solanumnigrum, Digeraarvensis, Trianthemamonogyna, Cyperusrotundus, Sorghum halepense, Cynodondactylon, Convolvulus arvensis, Digeraarvensis, Echinochloa spp., Panicum sp. (Table 2). At 60 DAP the prominent weed species were the sedges, Cyperusrotundus occupied 56.8 per cent share in total weed population. Whereas, the broad leaved annual weed, Amaranthushybridus and broad leaved perennial weed i.e. Solamumnigrum were in a very few numbers and constituted 13.4 per cent of the total weed population. The grasses, including Cynodondactylon and Echinochloa crus-galli, constituted $29.8 \%$ to total weed density (Table 3 ).

At 90 DAP the prominent weed species were the sedges and Cyperusrotundus occupied 35.6 per cent share in total weed population (Table 2). Whereas, the broad leaved annual weed, Amaranthushybridus and broad leaved perennial weeds i.eSolamumnigrum were in a very few numbers that constituted 17.3 per cent of the total weed population. Grasses including perennial (Cynodondactylon) and annual
(Echinochloa crus-galli) constituted $47.1 \%$ of total weed density (Table 4). At 120 DAP, sedges (Cyperusrotundus) and broad leaved weeds occupied 25.1 and 18.5 per cent share in total weed population, respectively. Whereas, the grasses contributed $55.3 \%$ to total weed density (Table 5). Change in weed flora with the advancement in crop growth may be attributed to changing micro-climate and weather conditions. It has been reported that grasses and sedges thrive well in sugarcane fields particularly during rainy months that coincides with post 90-days growth stage of sugarcane crop in sub-tropical north Indian conditions [12].

Different weed control treatments affected the weed type and density however the different types of weeds had varied response to different control methods at various growth stages (Table 6). Weed growth in the plots treated with sulfentrazone (pre-em; $900 \mathrm{~g}$ ai/ha) recorded significant decrease in weed density $\left(15.7,18.0\right.$ and $\left.28.3 / \mathrm{m}^{2}\right)$ and achieved highest increase (Fig. 2) in extent of weed control ( 82.1, 83.0 and 75.6\%) compared to the control treatment $\left(87.3,105.7\right.$ and $\left.116.0 \mathrm{plant} / \mathrm{m}^{2}\right)$ at the 60,90 and $120 \mathrm{DAP}$, respectively.

Table 2. Name and type of weeds found in sugarcane.

\begin{tabular}{lllll}
\hline Weed type & Life cycle & Family & Common name & Scientific name \\
\hline Broadleaf & Summer annual & Amaranthaceae & Pigweed, smooth & Amaranthushybridus \\
Broadleaf & Summer annual & Chenopodiaceae & Lambsquarters & Chenopodium album \\
Broadleaf & Annual & Portulacaceae & - & Portulacaoleracea \\
Broadleaf & Annual & Compositeae & Congress weed & Parthenium sp. \\
Broadleaf & perennial & Solanaceae & Black nightshade & Solamumnigrum \\
Broadleaf & Annual & Amaranthaceae & False Amaranth & Digeraarvensis \\
Broadleaf & Annual & & Carpet weed & Trianthemamonogyna \\
Sedges & Summer perennial & Cyperaceae & Purple nut-sedge & Cyperusrotundus \\
Grass & Perennial & Poaceae (Graminae) & Johnson grass & Sorghum halepense \\
Grass & Summer perennial & Poaceae & Bermuda grass & Cynodondactylon \\
Broadleaf & Perennial & Convolvulaceae & Field bindweed & Convolvulus arvensis \\
Grass & Annual & Poaceae (Graminae) & Barnyard grass & Echinochloa crus-galli \\
Grass & Annual & Gramineae & & Panicum sp. \\
\hline
\end{tabular}


Table 3. Effect of weed control methods on density of weeds(number $\left./ \mathrm{m}^{2}\right)$ in sugarcane at $60 \mathrm{DAP}$.

\begin{tabular}{|c|c|c|c|c|}
\hline Treatment & Grasses & Broadleaf & Sedges & Total \\
\hline Sulfentrazone PPI $480 \mathrm{~g}$ ai/ha & 44 & 8 & 48 & 100 \\
\hline Sulfentrazone PPI $600 \mathrm{~g}$ ai/ha & 32 & 4 & 30 & 66 \\
\hline Sulfentrazone PPI $720 \mathrm{~g}$ ai/ha & 30 & 0 & 30 & 60 \\
\hline Sulfentrazone PPI $900 \mathrm{~g}$ ai/ha & 34 & 0 & 17 & 51 \\
\hline Sulfentrazone Pre-em $480 \mathrm{~g}$ ai/ha & 36 & 8 & 86 & 130 \\
\hline Sulfentrazone Pre-em $600 \mathrm{~g}$ ai/ha & 20 & 8 & 52 & 80 \\
\hline Sulfentrazone Pre-em $720 \mathrm{~g}$ ai/ha & 21 & 5 & 54 & 80 \\
\hline Sulfentrazone Pre-em $900 \mathrm{~g}$ ai/ha & 15 & 10 & 22 & 47 \\
\hline Atrazine $50 \mathrm{WP}+2,4 \mathrm{D} 80 \%(60 \mathrm{DAP})$ & 28 & 8 & 90 & 126 \\
\hline Three hoeing & 13 & 12 & 48 & 73 \\
\hline Trash mulching & 16 & 4 & 74 & 94 \\
\hline $\mathrm{T} 2+$ one hoeing at $60 \mathrm{DAP}$ & 26 & 4 & 46 & 76 \\
\hline $\mathrm{T} 6+$ one hoeing at $60 \mathrm{DAP}$ & 24 & 0 & 64 & 88 \\
\hline Untreated control(weedy) & 58 & 108 & 96 & 262 \\
\hline Total & 397 & 179 & 757 & 1333 \\
\hline
\end{tabular}

Table 4. Effect of weed control methods on density of weeds $\left(N O . / m^{2}\right)$ in sugarcane at 90 DAP.

\begin{tabular}{|c|c|c|c|c|}
\hline Treatment & Grasses & Broadleaf & Sedges & Total \\
\hline Sulfentrazone PPI $480 \mathrm{~g}$ ai/ha & 65 & 22 & 37 & 124 \\
\hline Sulfentrazone PPI $600 \mathrm{~g}$ ai/ha & 55 & 18 & 23 & 96 \\
\hline Sulfentrazone PPI $720 \mathrm{~g}$ ai/ha & 53 & 0 & 13 & 66 \\
\hline Sulfentrazone PPI $900 \mathrm{~g}$ ai/ha & 50 & 0 & 8 & 58 \\
\hline Sulfentrazone Pre-em $480 \mathrm{~g}$ ai/ha & 82 & 20 & 55 & 157 \\
\hline Sulfentrazone Pre-em $600 \mathrm{~g}$ ai/ha & 65 & 22 & 30 & 117 \\
\hline Sulfentrazone Pre-em $720 \mathrm{~g}$ ai/ha & 46 & 13 & 29 & 88 \\
\hline Sulfentrazone Pre-em $900 \mathrm{~g}$ ai/ha & 36 & 8 & 10 & 54 \\
\hline Atrazine $50 \mathrm{WP}+2,4 \mathrm{D} 80 \% \mathrm{DAP}$ & 40 & 7 & 56 & 103 \\
\hline Three hoeings & 9 & 2 & 39 & 50 \\
\hline Trash mulching & 34 & 15 & 58 & 107 \\
\hline $\mathrm{T} 2+$ one hoeing at $60 \mathrm{DAP}$ & 18 & 3 & 33 & 54 \\
\hline $\mathrm{T} 6+$ one hoeing at $60 \mathrm{DAP}$ & 24 & 5 & 49 & 78 \\
\hline Untreated control(weedy) & 115 & 119 & 83 & 317 \\
\hline Total & 692 & 254 & 523 & 1469 \\
\hline
\end{tabular}

Table 5. Effect of weed control methods on density of weeds $\left(N_{0} . / m^{2}\right)$ in sugarcane at 120 DAP.

\begin{tabular}{|c|c|c|c|c|}
\hline Treatment & Grasses & Broadleaf & Sedge & Total \\
\hline Sulfentrazone PPI $480 \mathrm{~g}$ ai/ha & 100 & 26 & 16 & 142 \\
\hline Sulfentrazone PPI $600 \mathrm{~g}$ ai/ha & 91 & 27 & 11 & 129 \\
\hline Sulfentrazone PPI $720 \mathrm{~g}$ ai/ha & 94 & 18 & 6 & 118 \\
\hline Sulfentrazone PPI $900 \mathrm{~g}$ ai/ha & 74 & 3 & 8 & 85 \\
\hline Sulfentrazone Pre-em $480 \mathrm{~g}$ ai/ha & 104 & 36 & 26 & 166 \\
\hline Sulfentrazone Pre-em $600 \mathrm{~g}$ ai/ha & 80 & 32 & 23 & 135 \\
\hline Sulfentrazone Pre-em $720 \mathrm{~g}$ ai/ha & 44 & 9 & 36 & 89 \\
\hline Sulfentrazone Pre-em $900 \mathrm{~g}$ ai/ha & 40 & 20 & 25 & 85 \\
\hline Atrazine $50 \mathrm{WP}+2,4 \mathrm{D} 80 \% \mathrm{DAP}$ & 22 & 3 & 66 & 91 \\
\hline Three hoeings & 18 & 24 & 44 & 86 \\
\hline Trash mulching & 92 & 18 & 43 & 153 \\
\hline $\mathrm{T} 2+$ one hoeing at $60 \mathrm{DAP}$ & 30 & 24 & 38 & 92 \\
\hline T6 + one hoeing at 60 DAP & 40 & 14 & 42 & 96 \\
\hline Untreated control(weedy) & 175 & 101 & 72 & 348 \\
\hline Total & 1004 & 355 & 456 & 1815 \\
\hline
\end{tabular}

Table 6. Effect of weed control methods on weed density $\left(N o . / m^{2}\right)$ at different growth stages of sugarcane.

\begin{tabular}{lllll}
\hline Treatment & Time of application & Dose (g a.i./ha) & 60DAP & 90DAP \\
\hline Sulfentrazone & PPI & 840 & 33.3 & 41.3 \\
Sulfentrazone & PPI & 600 & 22.0 & 32.0 \\
Sulfentrazone & PPI & 720 & 20.0 & 47.3 \\
Sulfentrazone & PPI & 900 & 17.0 & 22.0 \\
Sulfentrazone & Pre-em: 3 DAP & 480 & 43.3 & 19.3 \\
Sulfentrazone & Pre-em: 3 DAP & 600 & 26.7 & 52.3 \\
Sulfentrazone & Pre-em: 3 DAP & 720 & 26.7 & 39.0 \\
Sulfentrazone & Pre-em: 3 DAP & 900 & 5.3 & 28.7 \\
\hline
\end{tabular}




\begin{tabular}{llllll}
\hline Treatment & Time of application & Dose (g a.i./ha) & 60DAP & 90DAP & 120DAP \\
\hline Atrazine 50 WP+2,4 D 80\% WP & Pre-em: 3DAP+60 DAP & $2000+1000$ & 42.0 & 34.3 & 30.3 \\
Three hoeing & 60,90,120 DAP & & 24.3 & 16.7 & 28.7 \\
Trash mulching & 3 DAP & - & 31.3 & 35.7 & 51.0 \\
T2 + one hoeing at 60 DAP & - & - & 25.3 & 18.0 & 30.7 \\
T6 + one hoeing at 60 DAP & - & - & 29.3 & 26.0 & 32 \\
Untreated control(weedy) & - & & 87.3 & 105.7 & 116.0 \\
L.S.D. 0.05 & & & 12.34 & 12.86 & 19.27 \\
\hline
\end{tabular}

\begin{tabular}{|c|}
\hline 口Sulfentrazone PPI840 \\
\hline 口Sulfentrazone PPI600 \\
\hline 口Sulfentrazone PPI720 \\
\hline 口Sulfentrazone PPI900 \\
\hline 口Sulfentrazone Pre-eme 480 \\
\hline$\square$ Sulfentrazone Pre-eme 600 \\
\hline$\square$ Sulfentrazone Pre-eme720 \\
\hline$\square$ Sulfentrazone Pre-eme 900 \\
\hline DAtrazine +2,4 D 2000+1000 \\
\hline 口Three hoeings $60,90,120$ DAP \\
\hline 口Trash mulching 3 DAP \\
\hline $\mathrm{QT2}+$ one hoeing at $60 \mathrm{DAP}$ \\
\hline$\square \mathrm{T} 6+$ one hoeing at 60 DAP \\
\hline 口Untreated control(weedy) \\
\hline
\end{tabular}

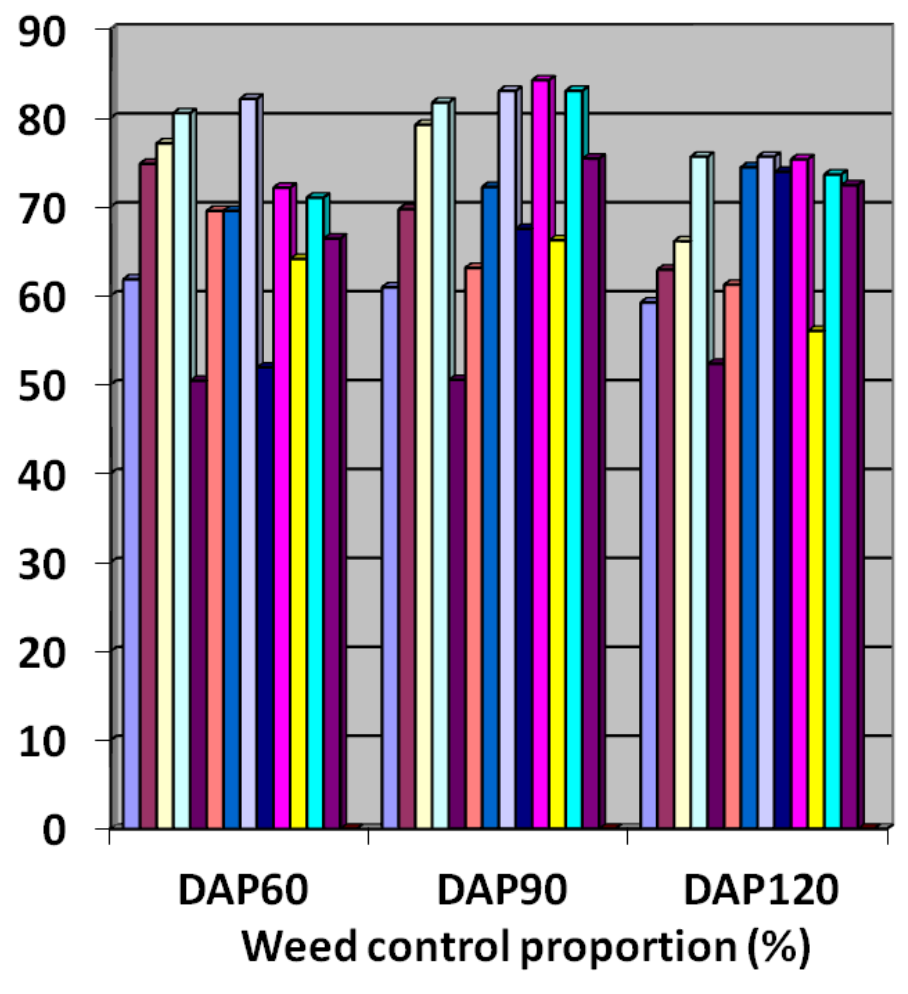

Figure 2. Effect of weed control methods on weed control extent (\%) at different growth stages of sugarcane.

Dry weight of weeds (g)

The research findings presented in table indicates that all the weed control treatments were effective in significantly reducing the dry weight of weeds as compared to that in. The dry matter accumulation in weeds was the lowest $(13.8,14.9$ and $53.7 \mathrm{~g} / \mathrm{m}^{2}$ ) in three-hoeing treatment which brought about significant reduction in dry matter production by weeds (93.2, 94.2 and $75.5 \%$ ) as compared with the control treatment (Fig. 2) $\left(203.9,259.3\right.$ and $\left.218.8 \mathrm{~g} / \mathrm{m}^{2}\right)$ at the 60,90 and 120 DAP respectively.

Table 7. Effect of weed control methods on dry matter production of weeds $\left(\mathrm{g} / \mathrm{m}^{2}\right)$ at different growth stagesof sugarcane.

\begin{tabular}{|c|c|c|c|c|c|}
\hline Treatment & Time of application & Dose (g ai/ha) & 60DAP & 90DAP & 120DAP \\
\hline Sulfentrazone & PPI & 840 & 33.1 & 66.7 & 136.7 \\
\hline Sulfentrazone & PPI & 600 & 24.6 & 61.1 & 132.5 \\
\hline Sulfentrazone & PPI & 720 & 21.7 & 42.9 & 117.7 \\
\hline Sulfentrazone & PPI & 900 & 15.7 & 34.7 & 116.4 \\
\hline Sulfentrazone & Pre-eme: 3 DAP & 480 & 33.7 & 57.4 & 136.1 \\
\hline Sulfentrazone & Pre-eme: 3 DAP & 600 & 31.4 & 50.2 & 121.9 \\
\hline Sulfentrazone & Pre-eme: 3 DAP & 720 & 26.5 & 46.9 & 114.7 \\
\hline Atrazine $50 \mathrm{WP}+2,4 \mathrm{D} 80 \%$ & Pre-em: $3 \mathrm{DAP}+60 \mathrm{DAP}$ & $2000+1000$ & 37.8 & 37.5 & 67.2 \\
\hline Three-hoeing & $60,90,120 \mathrm{DAP}$ & & 13.8 & 14.9 & 53.7 \\
\hline Trash mulching & 3 DAP & & 25.6 & 22.3 & 88.4 \\
\hline $\mathrm{T} 2+$ one hoeing at $60 \mathrm{DAP}$ & - & - & 30.9 & 27.7 & 68.7 \\
\hline T6 + one hoeing at $60 \mathrm{DAP}$ & - & - & 36.0 & 20.9 & 59.1 \\
\hline Untreated control(weedy) & - & - & 203.9 & 259.3 & 218.8 \\
\hline L.S.D 0.05 & & & 46.18 & 20.92 & 20.89 \\
\hline
\end{tabular}




\begin{tabular}{|l|}
\hline$\square$ Sulfentrazone PPI840 \\
$\square$ Sulfentrazone PPI600 \\
$\square$ Sulfentrazone PPI720 \\
$\square$ Sulfentrazone PPI900 \\
$\square$ Sulfentrazone Pre-eme 480 \\
$\square$ Sulfentrazone Pre-eme 600 \\
$\square$ Sulfentrazone Pre-eme 720 \\
$\square$ Sulfentrazone Pre-eme 900 \\
$\square$ Atrazine+2,4 D 2000+1000 \\
$\square$ Three hoeings 60,90,120 DAP \\
$\square$ Trash mulching 3 DAP \\
$\square T 2+$ one hoeing at 60 DAP \\
$\square T 6+$ one hoeing at 60 DAP \\
$\square$ Untreated control(weedy)
\end{tabular}

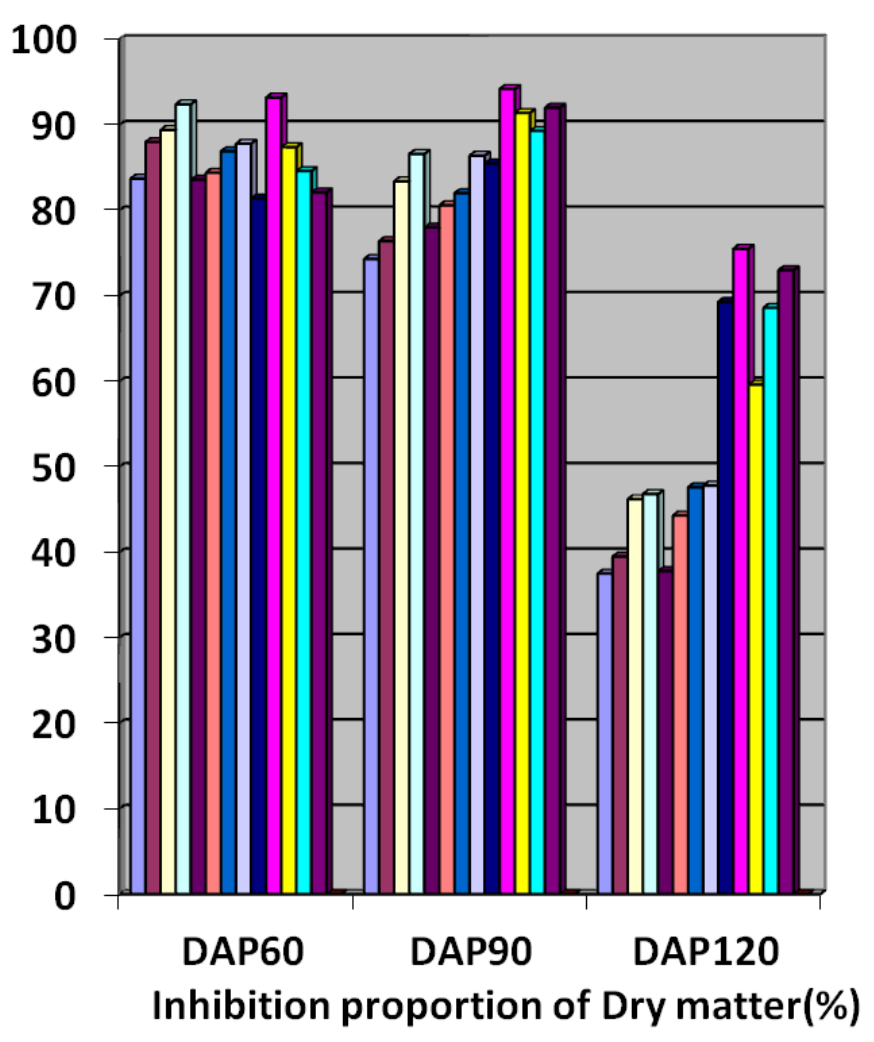

Figure 3. Effect of weed control methods on reduction of weed dry matter. production (\%) at different growth stages of sugarcane.

\section{References}

[1] Litlle, K. P. Adams, H. Frochet, J. Java, S. Gous, R. A. Lautenschlaget, G. Orlander, K. V. Sankaran, R. G. Wagnet, Run-PengWel, and I. Wiloughby. Reducing herbicide use through integrated forest vegetation management practices. Institute for Commercial Forestry Research, Scotsville, South Africa.2006.

[2] Anonymous. "Controlling Weeds in Sugarcane". Baton Rouge, LA. Louisiana State University AgCenter and Louisiana Cooperative Extension Service. Pub.2314 pp. 24.2001.

[3] KanchanNainwal.Weed Infestation in sugarcane.2009(C.F. ONLINE) WWW.atsdr.cdc.gov.

[4] Tomar, P.K., Om.Prakash, and D. Singh. Economical methods of weed management to improve the productivity and sugar recovery in late planted sugarcane. Indian Sugar, LIII (5): 339-342.2003.

[5] Singh, H., N. Kumar, and D.K. Dwivedi. Efficacy of some new herbicides on weed dynamics and yield of sugarcane. Indian Sugar, LVIII (9): 71-74.2008.
[6] Singh,A.K., R.S. Chauhan and T,K. Srivastava . Effect of preemergence application of sulfentrazone in spring planted sugarcane under sub-tropical India . International conference on APCHNE. 2012.

[7] Jonathan Siebert.Sugarcane seed response to 2,4-d and alternative herbicides for red morningglory (ipomoea coccinea 1.) control .Thesis, Louisiana State University. p: 67.2003.

[8] Krausz, R. F., G. Kapusta, J. L. Matthews. Sulfentrazone for weed control in soybean (Glycine max). Weed Technol. 12:684-689.1998.

[9] Stringer, S. J., E. V. Gage, H. G. Hancock, and L. D. Hatfield. Weed control in sugarcane with clomazone. Proc. South. Weed Sci. Soc. 51:219.1998.

[10] Vidrine, P. R., J. L. Griffin, D. L. Jordan and D. B. Reynolds. Broad leaf weed control in soybean (Glycine max) with sulfentrazone. Weed Technol. 10: 762 - 765.1996.

[11] Steel, R.G. and J.H.Torrie .Principles and procedures of statistics. MCGraw Hill Book company. Inc USA. Pp 485. 1980.

[12] Srivastava T. K. Bio-efficacy of Sulfentrazone againstNutsedge (Cyperusrotundus) and Other Weeds in Sugarcane. Indian Journal of Weed ScienceVo( 35): 1\&2.pp:82- 86.2003. 